\title{
Biometric differences in Ucides cordatus (LINNAEUS, 1763) (Crustacea; Brachyura; Ocypodidae) as an indicative of environmental stress
}

Growing urban development, port expansion, and the deployment of industries along the northeast coast of Brazil are some of the major threats to crustacean fauna that depend directly on the mangrove ecosystem to survive. In response to these environmental changes, the swamp ghost crab (Ucides cordatus) presents biological dysfunctions in body size to invest in mechanisms that regulate homeostasis. The present study aimed to evaluate the size and condition factor of crabs from two distinct mangrove areas, being an impacted area and a reference area. Male crabs were collected through the braking technique, weighed with an analytical balance and the width and length of the carapace were measured with a digital caliper. We used a t test to observe differences between two areas and different periods, and the power function $(y=a x b)$ for the ratio between the weight and width of the carapace of each individual was used in order to observe the type of growth. There were significant differences between the weight and length of the individuals between the two sample areas and the growth classified as negative allometric

\section{Diferenças biométricas de Ucides cordatus (LINNAEUS, 1763) (Crustacea; Brachyura; Ocypodidae) como indicativo de estresse ambiental}

\begin{abstract}
O crescente desenvolvimento urbano, a ampliação de portos e a implantação de indústrias ao longo da costa nordeste do Brasil são algumas das principais ameaças a fauna de crustáceos que dependem diretamente do ecossistema manguezal para sobreviver. Como resposta a essas mudanças ambientais, o caranguejo-uçá (Ucides cordatus) apresenta disfunções biológicas no tamanho corporal para investir em mecanismos que regulem a homeostase. O presente estudo teve por objetivo avaliar o tamanho e o fator de condição de caranguejos de duas áreas de mangue distintas, sendo uma área impactada e uma área de referência. Caranguejos machos foram coletados através da técnica do braceamento, pesados com auxílio de balança analítica e as medidas de largura e comprimento da carapaça foram mensuradas com auxílio de paquímetro digital. Utilizou-se test t para observar diferenças entre as áreas e entre os períodos, a função potência $(y=a x b)$ para a razão entre o peso e largura da carapaça de cada indivíduo foi usada para detectar o tipo de crescimento. Houve diferenças significativas entre o peso e comprimento dos indivíduos entre as duas áreas amostradas, sendo o crescimento classificado como alométrico negativo.
\end{abstract}

Palavras-chave: Fator de condição; Mangue; Impacto ambiental; Estratégias adaptativas.

Topic: Desenvolvimento, Sustentabilidade e Meio Ambiente

Reviewed anonymously in the process of blind peer.
Received: 02/02/2020 Approved: 09/03/2020
Carmen Hellen da Silva Rocha

Instituto Federal do Maranhão, Brasil

http://lattes.cnpq.br/4487213915336253

rochachs@hotmail.com

Ricardo Luvizotto Santos

Universidade Federal do Maranhão, Brasil

http://lattes.cnpq.br/77355429398886627

https://orcid.org/0000-0002-3828-8930

ricardo.luvizotto@ufma.br

Thamires Barroso Lima (iD)

Instituto Federal do Maranhão, Brasil

http://lattes.cnpq.br/1892566233693377

http://orcid.org/0000-0003-3417-4781

thamiresbloc@gmail.com
Marianna Basso Jorge (iD)

Universidade Federal do Maranhão, Brasi

http://lattes.cnpq.br/1185970315739551

https://orcid.org/0000-0002-8459-6707

mb.jorge@ufma.br

Iranaldo Santos da Silva (iD

Universidade Federal do Maranhão, Brasil

http://lattes.cnpq.br/1281555528581499

https://orcid.org/0000-0001-6216-9141

iranaldo.ss@ufma.br
Referencing this:

ROCHA, C. H. S.; SANTOS, R. L.; LIMA, T. B.; JORGE, M. B.; SILVA, I. S.. Biometric differences in Ucides cordatus (LINNAEUS, 1763) (Crustacea; Brachyura; Ocypodidae) as an indicative of environmental stress. Revista Ibero Americana de Ciências Ambientais, v.11, n.2, p.228235, 2020. DOI: http://doi.org/10.6008/CBPC21796858.2020.002.0024 


\section{INTRODUCTION}

Mangroves play a vital role in coastal zones, as they act as an important primary producer in estuarine environments (SOUZA et al., 2014), providing several living resources. This environment constitutes a natural nursery for different species that use this environment for spawning, refuge, reproduction, growth and feeding (OLIVEIRA, 2013).

In this ecosystem, crabs are closely related to the substrate, acting at different levels of the trophic chain either as herbivores, predators, necrophages or prey of other taxonomic groups (FERREIRA et al., 2014). Among the main species found in mangroves, the swamp ghost crab Ucides cordatus (LINNAEUS, 1763) (Crustacea; Brachyura; Ocypodidae) is a semi-terrestrial crustacean from typically estuarine regions, occurring from northern Florida to the coast of Santa Catarina in Brazil (LEITE et al., 2014; WELLENS et al., 2015; WUNDERLICH et al., 2008).

This species is an important component of the benthic fauna (ABDULLAH et al., 2016; MORAES et al., 2015), widely used as a food source in several Brazilian regions and it is economically important because it contributes to the income of many fishermen (HATTORI et al., 2003).

Despite the ecological relevance, the habitat of this species has been altered due to overexploitation of forest products and expansion of human populations in coastal zones (FERREIRA et al., 2016). Consequently, the quality of the environment is threatened by physical and chemical components (ADAMCZUK et al., 2015), such as sedimentation, eutrophication, pollution by toxic substances, heavy metals among others (AVIGLIANO et al., 2015; TIQUIO et al., 2017).

The effects of these natural and anthropogenic stressors may reflect on the body development of some species of crabs, since organisms present in more impacted areas present greater body asymmetry due to the energy expenditure to control the stress promoted by the environment in which they live (LEZCANO et al., 2015; MATHESON et al., 2012). This ecological imbalance can alter the entire reproduction cycle of a given species (JERÔNIMO et al., 2012).

In this sense, species biometry is able to provide information about structure and morphological maturity (LIMA et al., 2006), to estimate the type of growth that organisms present when the conditions are favorable (isometric) or unfavorable (allometric) to their well-being (RODRIGUES et al., 2015), besides showing possible adaptive differences (MORAES et al., 2015) and unequal growth rates in impacted areas in comparison to populations of more preserved areas (ARAÚJO et al., 2012).

According to Moraes et al. (2015), there are no studies comparing the size of Ucides cordatus among mangroves in areas of greater anthropic impact with those of more preserved areas within the same geographic region. Thus, the main objective of this study is to evaluate possible differences between body measurements of crabs in different areas in order to infer about the influence of environmental integrity on the biometrics of these animals. 


\section{MATERIALS AND METHODS}

\section{Study area}

The samplings were carried out in two distinct areas on the island of Maranhão. The impacted area (IA) comprises the Coqueiro region (0243'43.5' S and $44^{\circ} 21^{\prime} 44.5^{\prime \prime} \mathrm{W}$ ) and receives the influence of the port complex of Itaqui.

This port is part of the second largest port cargo handling complex in the country and has an important activity in the transportation of mainly minerals, petroleum and its by-products (GOBBI et al., 2017), which imply different environmental impacts for this area (SAMARITANO et al., 2013).

In this area, studies such as that of Silva et al. (2014) evaluated and verified contamination of water and sediment by metals ( $\mathrm{Cu}, \mathrm{Pb}, \mathrm{Zn}, \mathrm{Cd}, \mathrm{Ni}, \mathrm{Fe}, \mathrm{Al}$ and $\mathrm{Mn}$ ), in addition to environmental and social changes caused by the installation of a thermoelectric plant near the port.

The reference area (RA) located in the region of Raposa ( $2^{\circ} 26^{\prime} 48.3^{\prime \prime} \mathrm{S}$ and $\left.44^{\circ} 04^{\prime} 41.6^{\prime \prime} \mathrm{W}\right)$ (Fig. 1), in the Bay of São José and it is characterized by the absence of direct anthropic impacts, which are visible in its surroundings, due to its difficult access resulted from the distance from inhabited areas.

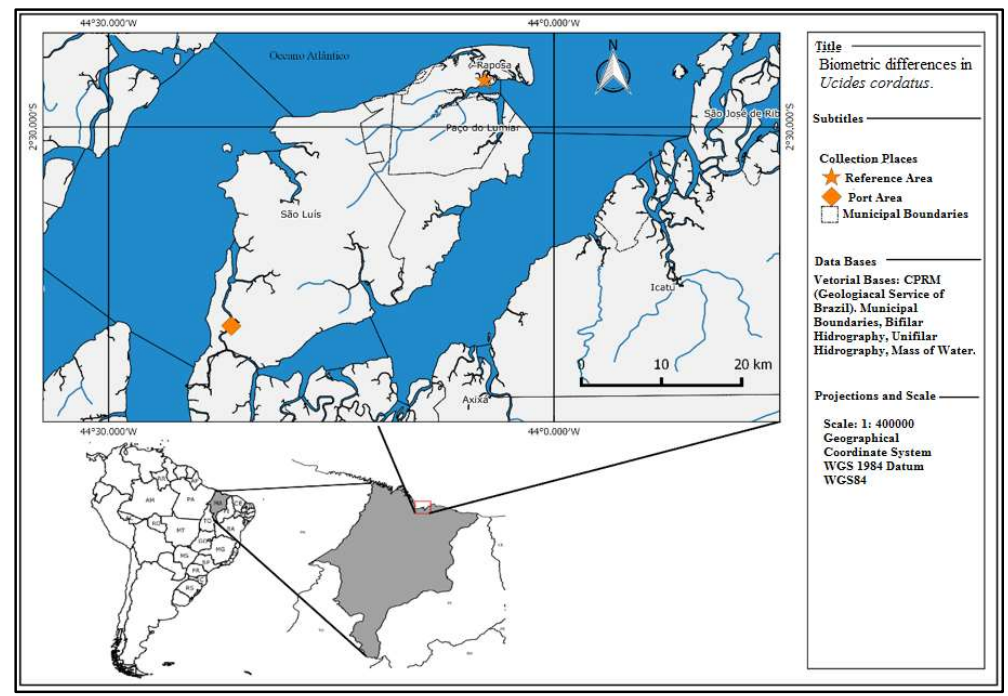

Figure 1: Location of sampling points on the island of Maranhão.

\section{Animals sampling}

Crabs were collected in the dry and rainy periods, between October and December 2015 and between March and May 2016, through the braking technique (ARAÚJO et al., 2013).

The sexual characterization of the organisms was obtained macroscopically, since these individuals present evident sexual dimorphism in the abdomen (AMARAL et al., 2014), in this way, only the male individuals were collected.

Measurements of carapace width and length were measured using a digital caliper and body mass was determined on a digital scale (0.01g). 


\section{Statistical analysis}

Normality of data distribution was assessed using a Shapiro-Wilk test and the equality of variances or homoscedasticity was analyzed by Levene's test (FARAWAY, 2002). For data with normal distribution, a t test was used in order to evaluate the existence of differences of biometric data between the two areas and between different periods.

The ratio between the weight of each individual and the width of the carapace ( $\mathrm{Hw} \times \mathrm{Cw}$ ) were defined from potential equations $y=a x^{b}$. Regression analysis by the potential function was used to verify types of growth through the $\mathrm{b}$ value. In relation to $\mathrm{Hw} \times \mathrm{Cw}$, the type of growth is classified as: isometric (b $=3)$, positive allometric $(b>3)$ or negative allometric $(b<3)$. Analyzes were conducted on the $R$ version 3.2 .5 platform (R CORE TEAM, 2016).

\section{RESULTS}

A total of 104 specimens of Ucides cordatus were measured and weighted, being 52 of AR and 52 of Al. Individuals collected in the reference area were distinguished by their size and weight in relation to the individuals collected in the Al. These organisms showed carapace length ranging from $39-71 \mathrm{~cm}$; Carapace width varied between $50-81 \mathrm{~cm}$ and the weight varied between 80 and $217 \mathrm{~g}$, while organisms collected in the Al were smaller on average in all biometric aspects evaluated (Table I).

Table I: Biometric data with mean and standard deviation values for sampling periods and locations.

\begin{tabular}{|l|l|l|l|}
\hline Dry & Weight $(\mathrm{g})$ & Width $(\mathrm{mm})$ & Length $(\mathrm{mm})$ \\
\hline RA* & $150.73 \pm 36.43$ & $66.46 \pm 7.16$ & $49.0 \pm 5.41$ \\
\hline IA* & $87.57 \pm 22.65$ & $61.16 \pm 5.32$ & $46.38 \pm 3.58$ \\
\hline Rainy & Weight $(\mathrm{g})$ & Width $(\mathrm{mm})$ & Length $(\mathrm{mm})$ \\
\hline RA & $150.88 \pm 27.93$ & $69.03 \pm 5.19$ & $52.92 \pm 5.13$ \\
\hline IA & $104.80 \pm 25.92$ & $63.80 \pm 4.72$ & $47.11 \pm 4.26$ \\
\hline
\end{tabular}

RA-Reference area (Raposa); IA- Impacted area (Coqueiro).

Between dry and rainy periods, only carapace length showed significant differences $(p<0.05)$. The carapace weight, width and length were significantly different between RA and IA $(p<0.05)$ (Fig 2$)$.

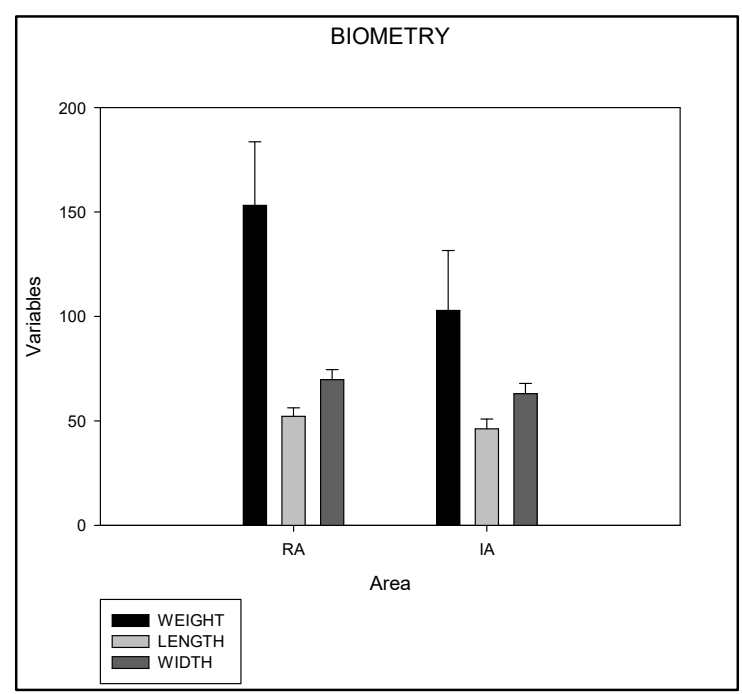

Figure 2: Values of weight $(\mathrm{g})$, width $(\mathrm{mm})$ and carapace length $(\mathrm{mm})$ for Ucides cordatus crab between RA and IA. 
The relationship between carapace weight and width was stronger in RA ( $R 2=0.62$ ). Equations between $\mathrm{Hw} \times \mathrm{Cw}$ for $\mathrm{RA}(\mathrm{b}=1,8)$ and IA $(b=2,6)$ showed constant values lower than 3 and indicated negative allometric growth (Figure 3).
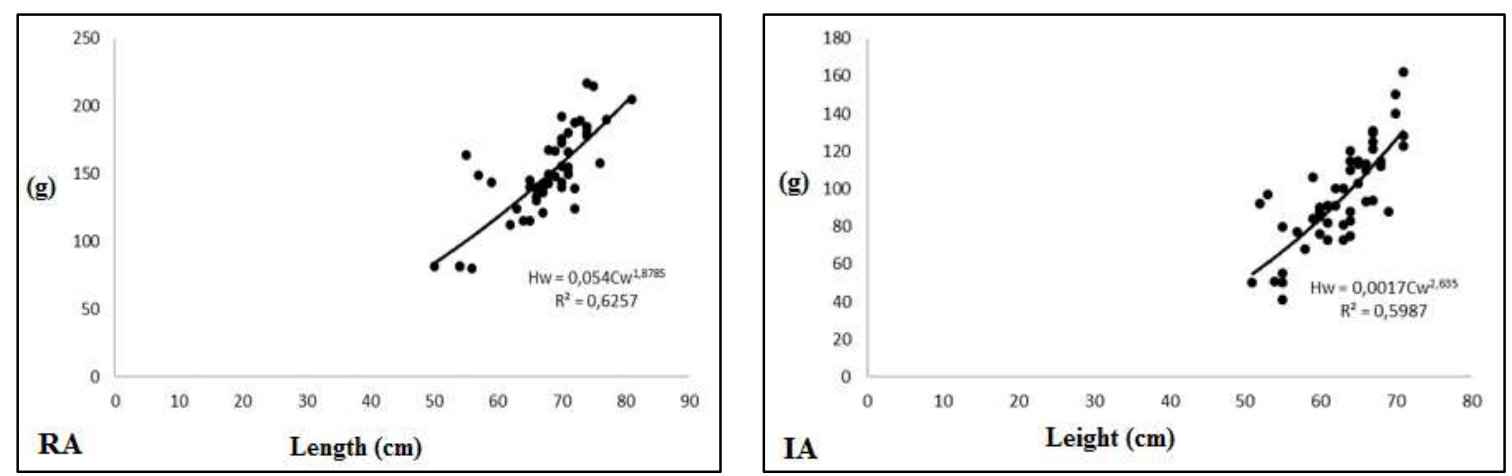

Figure 3: Weight and length relationship for Raposa and Coqueiro (RA = reference area, IA= impacted area, $\mathrm{Hw}=$ weight $(\mathrm{g}), \mathrm{Cw}=$ carapace width $(\mathrm{cm}))$.

\section{DISCUSSION}

Data from the present study show significant differences between weight and length of individuals between two sampled areas. Individuals of the Al presented significantly smaller size and body weight when compared with AR individuals. These differences may be related to the high concentrations of metals found in São Marcos Bay (SILVA et al., 2014), due to the presence of a port complex and an expressive number of dwellings that can make the environment harmful to aquatic and terrestrial biota (SOUZA et al., 2013).

Research carried out in estuaries of Pernambuco state showed that the crabs in more impacted areas were smaller when compared to low impact areas (CASTIGLIONI et al., 2009). Similar results were found by Araújo et al. (2012) when observing that the growth rates of Ucides cordatus were unequal between mangroves of Ariquindá and Mamucabas due to the deforestation and the deposition of residues found in this last estuary.

According to Moraes et al. (2015), these differences may be result of ecological strategies adopted by species to adapt to poor environmental quality found in many coastal areas. Therefore, it is believed that in situations of environmental stress, crabs tend to spend more energy to maintain homeostasis and, consequently, the availability of energy to invest in other physiological processes will be lower.

One of the main impacts on mangrove ecosystem is related to pollution by domestic and industrial effluents which directly influence the concentration of heavy metals in the soil (SUNDARAMANICKAM et al., 2016) and in the roots and leaves of different mangrove species (QINHANG et al., 2014), which are an integral part of the diet of U. cordatus (NORDHAUS et al., 2007). The greater the contribution of contaminants in the area, the greater the risk of absorption by biota. In this sense, species with low mobility accumulate higher concentrations of metals (CHAPMAN et al., 2013), so the effect of biomagnification in the trophic chain can lead to bioaccumulation of xenobiotics in organisms and interfere in growth of these species (PINHEIRO et al., 2012). 


\section{CONCLUSIONS}

Another factor to be considered is the intense commercial exploitation of these organisms, which can interfere in density (DUARTE et al., 2016), yield and size of these animals (NASCIMENTO, 2017). Branco (1993) found minimum values of $53 \mathrm{~mm}$ and maximum values of $96 \mathrm{~mm}$ of width in crabs in the state of Santa Catarina, being larger than those of the northeastern region. According to the author, even with favorable climatic conditions, the demand for consumption is more intense in this region and exploitation influences the development of individuals. Tourism is also a relevant factor in over-exploitation of this species (AMARAL et al., 2014).

Thus, contamination levels in São Marcos Bay (SILVA et al., 2014), coupled with constant exploration of this species, since it is an area with easy access to the collectors, can favor the observed biometric differences.

The results found in this study are important for management plans since they allow evidencing and monitoring of environmental impacts in coastal zones. In addition, this work opens doors for other studies to be carried out in this region in order to evaluate the concentration of metals in crabs' tissue, as well as the use of specific biomarkers in order to obtain a diagnosis of biota health before toxic effects are triggered, as well as food poisoning of local population through consumption of crab meat.

ACKNOWLEDGEMENTS: The authors thank the Postgraduate Program in Biodiversity and Conservation, the Coordination for Improvement of Higher Education Personnel (CAPES) for financial support granted through the scholarship, the Laboratory of Central Analytical and the Laboratory of Ecology and Systematics of Fishes of the Federal University of Maranhão for the infrastructure provided for analysis processing. All samples taken in this study were performed according to state and federal laws in force (ICMBio 14340-1).

\section{REFERENCES}

ABDULLAH, M. M.; LEE, S. Y.. Meiofauna and crabs in mangroves and adjoining sandflats: Is the interaction physical or trophic?. Journal of Experimental Marine Biology and Ecology, v.479, p.69-75, 2016.

ADAMCZUK, M.; MIECZAM, T.; NAWROT, D.; RECHULICZ, J.. Indirect effect of environmental factors on interactions between microbial and classical food webs in freshwater ecosystems. Annales de Limnologie - International Journal of Limnology, v.51, p.49-58, 2015.

AMARAL, K. D. S.; VIEIRA, I. M.; OSÓRIO, F. M.; ROCHA, J. D. M.; LIMA, J. F.. Bioecology of the crab Ucides cordatus (Crustacea, Decapoda) in mangroves influenced by the Amazon River, Brazil. Acta Amazonica, v.44; p.213-222, 2014.

ARAÚJO, A. R. R.; FÉ, U. M. G. S.. Selectivity and Efficiency of Fishing Gear Used in the Capture of Ucides cordatus (LINNAEUS, 1763), Sergipe, Brazil. Actapesca, v.1, p.29-44, 2013.

ARAÚJO, M. S. L. C.; CASTIGLIONI, D. S.; COELHO, P. A..
Width-weight relationship and condition factor of Ucides cordatus (Crustacea, Decapoda, Ucididae) at tropical mangroves of Northeast Brazil. Iheringia Zoology Series, v.102, p.277-284, 2012.

AVIGLIANO, E.; SCHENONE, N. F.; VOLPEDO, A. V.. Heavy metals and trace elements in muscle of silverside (Odontesthes bonariensis) and water from different environments (Argentina): aquatic pollution and consumption effect approach. Science of The Total Environment, v.506, p.102-108, 2015.

BRANCO, J. O.. Bioecological aspects of the crab Ucides cordatus (Linnaeus, 1763) (Crustacea, Decapoda) of the Itacorubi mangrove, Santa Catarina, Brazil. Brazilian Archives of Biology and Technology, v.36, p.133-148, 1993.

CASTIGLIONI, D. S.; COELHO, P. A.. Determination of the sexual maturity of Ucides cordatus (Crustacea, Brachyura, Ucididae) in two mangrove areas of the south coast of Pernambuco, Brazil. Iheringia Zoology Series, v.101, p.1-2, 2009. 
CHAPMAN, E. E. V.; DAVE, G.; MURIMBOH, J. D.. A review of metal $(\mathrm{Pb}$ and $\mathrm{Zn})$ sensitive and $\mathrm{pH}$ tolerant bioassay organisms for risk screening of metal-contaminated acidic soils. Environmental Pollution, v.179, p.326-342, 2013.

DUARTE, L. F. A.; SOUZA, C. A.; NOBRE, C. R.. Multi-level biological responses in Ucides cordatus (Linnaeus, 1763) (Brachyura, Ucididae) as indicators of conservation status in mangrove areas from the western atlantic. Ecotoxicology and Environmental Safety, v.133, p.176-187, 2016.

FARAWAY, J. J.. Practical regression and Anova using $\mathbf{R}$. 2002.

FERREIRA, A. C.; LACERDA, L. D.. Degradation and conservation of Brazilian mangroves, status and perspectivas. Ocean and Coastal Management, v.125, p.3846, 2016.

FERREIRA, W. R.; LIGEIRO, R.; MACEDO, D. R.; HUGHES, R. M.; KAUFMANN, P. R.; OLIVEIRA, L. G.; CALLISTO, M. Importance of environmental factors on the richness and distribution of benthic macroinvertebrates in tropical headwater streams. Freshwater Science, v.33, p.860-871, 2014.

GOBBI, C. N.; SANCHES, V. M. L.; PACHECO, E. B. A. V.; GUIMARÃES, M. J. O. C.; FREITAS, M. A. V.. Management of plastic wastes at Brazilian ports and diagnosis of their generation. Marine Pollution Bulletin, v.124, p.67-73, 2017.

HATTORI, G. Y.; PINHEIRO, M. A. A.. Fertility of the mangrove crab Ucides cordatus (Linnaeus) (Crustacea, Brachyura, Ocypodidae), at Iguape (São Paulo), Brazil. Brazilian journal of zoology, v.20, n.2, 2003.

JERÔNIMO, C. E.; BALBINO, C. P.. Physical-Chemical Characterization of Carcinogen Effluents and Their Impacts to the Environment. Electronic Magazine in Environmental Management, Education and Technology, v.8, p.1639-1650, 2012.

LEITE, M. M. L.; OGAWA, C. Y.; REZENDE, C. F.; SILVA, J. R. F.. Temporal variation in the weight-size relationship of the mangrove crab Ucides cordatus L. (Decapoda: Ucididae) in relation to its life cycle phases. Animal Biology, v.64, p.333342, 2014

LEZCANO, A. H.; QUIROGA, M. L. R.; LIBEROFF, A. L.; MOLEN, S. V. D.. Marine pollution effects on the Southern surf crab Ovalipes trimaculatus (Crustacea: Brachyura: Polybiidae) in Patagonia Argentina. Marine Pollution Bulletin, v.91, p.524529, 2015.

LIMA, G. V.; OSHIRO, L. M. Y.. Somatic growth of the crabuçá Ucides cordatus (Crustacea, Brachyura, Ocypodidae) in laboratory. Iheringia Zoology Series, v.96, p.467-472, 2006.

MATHESON, K.; GAGNON, P.. Effects of temperature, body size, and chela loss on competition for a limited food resource between indigenous rock crab (Cancer irroratus Say) and recently introduced green crab (Carcinus maenas L.). Journal of Experimental Marine Biology and Ecology, v.428, p.49-56, 2012.

MORAES, E. E. B.; NUNES, B. J. B. M.; PINHEIRO, M. A. A. Population biology of the 'uçá'-crab, Ucides cordatus
(Linnaeus, 1763) (Brachyura: Ucididae), in mangroves of the Joanes River, Bahia State, Brazil. Nauplius, v.23, p.59-71, 2015.

NASCIMENTO, D. M.; ALVES, R. R. N.; BARBOZA, R. R. D. SCHMIDT, A. J.; DIELE, K.; MOURÃO, J. S.. Commercial relationships between intermediaries and harvesters of the mangrove crab Ucides cordatus (Linnaeus, 1763) in the Mamanguape River estuary, Brazil, and their socio-ecological implications. Ecological Economics, v.131, p.44-51, 2017.

NASCIMENTO, D. M.; MOURÃO, J. S.; ALVES, R. R. N.. The Substitution of the Traditional Techniques of Capture of the Uça Crab (Ucides cordatus) by the technique "redinha" in the Mamanguape River Estuary, Paraíba. Sitientibus Biological Sciences Series, v.11, p.113-119, 2011.

NORDHAUS, I.; WOLFF, M.. Feeding ecology of the mangrove crab Ucides cordatus (Ocypodidae): food choice, food quality and assimilation efficiency. Marine Biology, v.151, p.16651681,2007

OLIVEIRA, P. J. A.; COELHO, P. A.; CASTIGLIONI, D. S. Population biology of Ucides cordatus (Linnaeus, 1763) (Crustacea, Brachyura, Ucididae) from two tropicais mangroves sites in northeast coast of Brazil. Pan-American Journal of Aquatic Sciences, v.8, p.89-103, 2013.

PINHEIRO, M. A. A.; FISCARELLI, A. G.. Length-weight relationship of the carapace and condition factor of the mangrove crab Ucides cordatus (Linnaeus, 1763) (Crustacea, Brachyura, Ucididae). Brazilian Archives of Biology and Technology, v.52, p.397-406, 2009.

QINHAG, W. U.; TAM, N. F. Y.; LEUNG, J. Y. S.; ZHOU, X.; FU, J.; YAO, B.; HUANG, X.; XIA, L.. Ecological risk and pollution history of heavy metals in Nansha mangrove, South China. Ecotoxicology and Environmental Safety, v.104, p.143-151, 2014.

R CORE TEAM. R: A language and environment for statistical computing. Vienna: R Foundation for Statistical Computing, 2016.

SAMARITANO, L.; CHAGAS, F. M.; BERNARDINO, J. C. M. SIEGLE, E.; TESSLER, M. G.; UEMURA, S.. Hydrodynamic modeling over a sand wave field at São Marcos Bay, Brazil. In: INTERNACIONAL CONFERENCE ON MARINE AND RIVER DUNE DYNAMICS, BRUGGE, BELGIM, 4. Anais. MARIDIV Proceedings, 2013.

SILVA, G. S.; NASCIMENTO, A. S.; SOUSA, E. R.; MARQUES, E. P.; MARQUES, A. L. B.; CORRÊA, L. B.; SILVA, G. S.

Distribution and Fractionation of Metals in Mangrove Sediment from the Tibiri River Estuary on Maranhão Island. Brazilian jornal of chemistry, v.6, p.323-336, 2014.

SOUZA, I. C.; MOROZESK, M. ; DUARTE, I. D.; BONOMO, M. M.; ROCHA, L. D.; FURLAN, L. M.; ARRIVABENE, H. P.; MONFERRÁN, M. V.; MATSUMOTO, S. T.; MILANEZ, R. D.; WUNDERLIN, D. A.; FERNANDES, M. N.. Matching pollution with adaptive changes in mangrove plants by multivariate statistics. A case study, Rhizophora mangle from four neotropical mangroves in Brazil. Chemosphere, v.108, p.115-124, 2014.

SOUZA, I. C.; DUARTE, I. D.; PIMENTEL, N. Q.; ROCHA, L. D.; 
MOROSESK, M.; BONOMO, M. M.; AZEVEDO, V. C.; PEREIRA, C. D. S.; MONFERRÁN, M. V.; MILANEZ, C. R. D.;

MATSUMOTO, S.; WUNDERLIN, D. A.; FERNANDES, M. N.. Matchingmetal pollution with bioavailability, bioaccumulation and biomarkers response in fish (Centropomus parallelus) resident in neotropical estuaries. Environmental Pollution, v.180, p.136144, 2013.

SUNDARAMANICKAM, A.; SHANMUGAN, N.; CHOLAN, S.; KUMARESAN, S.; MADESWARAN, P.; BALASUBRAMANIAN, T.. Spatial variability of heavy metals in estuarine, mangrove and coastal ecosystems along Parangipettai, Southeast coast of India. Environmental Pollution, v.218, p.186-195, 2016.

TIQUIO, G. J. P.; MARMIER, N. P.. Management frameworks for coastal and marine pollution in the European and South
East Asian regions. Ocean and Coastal Management, v.135, p.65-78, 2017.

WELLENS, S.; SANDRINI-NETO, L.; GONZÁLEZ-

WANGUEMERT, M.; LANA, P.. Do the crabs Goniopsis cruentata and Ucides cordatus compete for mangrove propagules? A field-based experimental approach. Hydrobiologia, v.757, p.117-128, 2015.

WUNDERLICH, A. C.; PINHEIRO, M. M. A.; RODRIGUES, A. M.. Biology of the mangrove uçá crab, Ucides cordatus (Crustacea: Decapoda: Brachyura), in Babitonga Bay, Santa Catarina, Brazil. Revista Brasileira de Zoologia, v.25, p.188198, 2008.

A CBPC - Companhia Brasileira de Produção Científica (CNPJ: 11.221.422/0001-03) detém os direitos materiais desta publicação. Os direitos referem-se à publicação do trabalho em qualquer parte do mundo, incluindo os direitos às renovações, expansões e disseminações da contribuição, bem como outros direitos subsidiários. Todos os trabalhos publicados eletronicamente poderão posteriormente ser publicados em coletâneas impressas sob coordenação da Sustenere Publishing, da Companhia Brasileira de Produção Científica e seus parceiros autorizados. Os (as) autores (as) preservam os direitos autorais, mas não têm permissão para a publicação da contribuição em outro meio, impresso ou digital, em português ou em tradução. 